\title{
Books by Our Readers
}

\section{SPOTLIGHT}

Trouble in the University: How the Education of Health Care Professionals Became Corrupted Mildred A. Schwartz Brill

From the Publisher: In Trouble in the University, Mildred A. Schwartz analyzes how changes in US higher education affecting the health care professions and in the relations between universities and the state have created conditions that can give rise to corruption. Citing University of Medicine and Dentistry of New Jersey, Schwartz discusses how the connections between changing conditions and organizational structures can lead to illegal and unethical behavior. Because that university's experiences were not unique, they can be used to demonstrate how higher education has become vulnerable to corruption. Identification of the structural and cultural sources of corruption also suggests possible ways it could be avoided.

Mildred A. Schwartz, PhD (1965), Columbia University, is Professor Emerita of Sociology at the University of Illinois at Chicago, Visiting Scholar at New York University. A political sociologist.

Activating Democracy in Brazil: Popular Participation, Social Justice, and Interlocking Institutions

Brian Wampler

University of Notre Dame Press

Battle for the Big Sky: Representation and the Politics of Place in the Race for the US Senate

David Parker

CQ Press

The Bigot Today: Why Prejudice Persists Stephen Eric Bronner Yale University Press

Canadian Democracy from the Ground Up: Perceptions and Performance

Elisabeth Gidengil and Heather Bastedo, editors

The University of British Columbia Press
Civil War Interventions and Their Benefits:

Unequal Return

Isaac M. Castellano

Lexington Books

Congressional Primary Elections

Robert Boatright

Routledge

Dead Men Ruling: How to Restore Fiscal Freedom and Rescue Our Future

C. Eugene Steuerle

Century Foundation Press

Fighting for Votes: Parties, the Media, and Voters in an Ontario Election

William P. Cross, Jonathan Malloy, Tamara A. Small, and Laura B. Stephenson The University of British Columbia Press

Judging Judges: Values and the Rule of Law

Jason E. Whitehead

Baylor University Press

Oxford Handbook of U.S. Social Policy

Daniel Beland, Christopher Howard, Kimberly J. Morgan, editors

Oxford University Press

Political Communication in Canada: Meet the Press and Tweet the Rest

Alex Marland, Thierry Giasson, and

Tamara A. Small, editors

The University of British Columbia Press

Political Rhetoric: A Presidential Briefing Book

Mary E. Stuckey

Transaction Publishers

Recognition versus Self-Determination: Dilemmas of Emancipatory Politics

Avigail Eisenberg, Jeremy

Webber, Glen Coulthard, and

Andrée Boisselle, editors

The University of British

Columbia Press

Reviving Social Democracy: The Near Death and Surprising Rise of the Federal NDP

David Laycock and Lynda Erickson, editors

The University of British Columbia Press

Revolt on the Right: Explaining Support for the Radical Right in Britain

Robert Ford and Matthew J. Goodwin Routledge
Rightlessness in an Age of Rights: Hannah Arendt and the Contemporary Struggles of Migrants

Ayten Gündoğdu

Oxford University Press

Sex, Lies, and the Ballot Box: 50 Things You Need to Know about British Elections Philip Cowley and Robert Ford, editors Biteback Publishing

Shakespeare and Politics: What a Sixteenth-Century Playwright Can Tell Us about Twenty-First-Century Politics Bruce Altschuler and Michael Genovese Paradigm Publishers

Territorial Pluralism: Managing Difference in Multinational States

Karlo Basta, John McGarry, and Richard Simeon, editors

The University of British Columbia Press

Transgender Rights and Politics: Groups, Issue Framing, \& Policy Adoption Jami K. Taylor and Donald P. HaiderMarkel, editors

University of Michigan Press

\section{SPOTLIGHT}

Lincoln Gordon: Architect of Cold War Foreign Policy

Bruce L. R. Smith

University Press of Kentucky

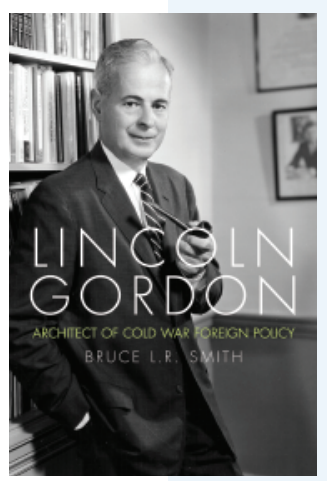

From the Publisher: In this impressive biography, Bruce L. R. Smith examines Lincoln Gordon's substantial contributions to US mobilization during the Second World War, Europe's postwar economic recovery, the security framework for the North Atlantic Treaty Organization (NATO), and US policy in Latin America. He also highlights the vital efforts of the advisers who helped Gordon plan NATO's force expansion and implement America's dominant foreign policy favoring free trade, free markets, and free political institutions.

Bruce L. R. Smith is a retired professor of political science at Columbia University and a Brookings Scholar. He is currently affiliated with the School of Public Policy at George Mason University. 